\title{
PELATIHAN PERAKITAN KOMPUTER, INSTALL SISTEM OPERASI DAN PEMASANGAN JARINGAN LOKAL DAN INTERNET UNTUK MEMBANGUN JARINGAN WARNET, PERKANTORAN DAN INTERNET DESA DALAM MENINGKATKAN KEMANDIRIAN SISWA SMK TUNAS PELITA DAN SMK ABDI NEGARA KOTA BINJAI
}

\author{
Akim Manaor Hara Pardede; Novriyenni \\ Dosen STMIK KAPUTAMA \\ Jl. Veteran No. 4A-9A, Binjai ,Sumatera Utara \\ akimmhp@live.com
}

\begin{abstract}
Abstrak
The development of information and communication technology is increasing in accordance with the changing times and needs of today's society, so that almost any activity or work is already subject and applying information technology and communication. The development of information technology and impact to the world of education, so that the public interest to major in computer informatics include Computer Network, Audio Visual, Graphic Design, Information Technology, etc. continue to increase both the level of high school or college level. Many enthusiasts of computer majors resulted in strong competition for the graduates to get jobs, so it needs no efforts to improve the skills and graduate students majoring in computer that does not merely want to find a job but was able to create job. STMIK Kaputama continue to perform activities of teaching, research and community service, see the strong competition of graduates and the needs of society Binjai and surrounding areas, lecturer STMIK Kaputama feel compelled to carry out community service to improve the skills of students SMKTunasPelita and AbdiNegara in the form of training computer assembly, installation of operating systems and installation of local networks and the internet to build a network of internet cafes, offices and internet village in increasing independence. With their training computer assembly, installation of operating systems and the installation of local networks and the Internet, it is expected students SMKTunasPelita and SMKAbdiNegara can further enhance the skills and
\end{abstract}


TECHSI : Jurnal Penelitian Teknik Informatika

entrepreneurial spirit so that they are capable of self-employed at the same time create jobs specifically to be able to receive computer repair and network cafe, internet network of offices and internet networks into the village. In addition to their entrepreneurial spirit, especially rural society also helped that the acceleration of information and communication can be further increased.

\section{Key Words: Computer assembly, Network Computer, Internet, Internet Cafe, Office Network, Network Village, Vocational Entrepreneurship.}

\section{Pendahuluan}

\subsection{Analisa Situasi Kota Binjai}

Kota Binjai sebagai salah satu kota di Propinsi Sumatera Utara yang hanya berjarak $\pm 22 \mathrm{Km}$ dari Kota Medan ( \pm 30 menit perjalan ), bahkan batas terluar Kota Binjai dengan batas terluar Kota Medan hanya berjarak $\pm 8 \mathrm{Km}$. Kota Binjai berbatasan langsung dengan Kabupaten Deli Serdang dan Kabupaten Langkat, serta berada pada Jalur Trasportasi Utama yang menghubungkan Propinsi Sumatera Utara dengan Propinsi Nangroe Aceh Darurralam (NAD) serta ke Objek Wisata Bukit Lawang Kabupaten Langkat. Secara geografis Kota Binjai terletak pada posisi $3^{\circ} 31^{\prime} 31^{\prime \prime}-3^{\circ} 40^{\prime} 2^{\prime \prime}$ LU dan $98^{\circ} 27^{\prime} 3^{\prime \prime}-98^{\circ} 32^{\prime}$ 32" BT dan terletak $\pm 28 \mathrm{M}$ di atas permukaan laut.

Kota Binjai yang memiliki luas 9.023,62 Ha ( \pm 90,23 Km2) terdiri dari 5 (lima) Kecamatan dan 37 (tiga puluh tujuh) Kelurahan serta mempunyai penduduk sebanyak 252.652 jiwa yang terdiri dari berbagai Etnis antara lain Melayu,Batak Toba, Batak Mandailing, Batak Karo, Batal Simalungun , Jawa, Banten, Minang, Aceh, China dan India dengan pemeluk agama mayoritas Islam dan yang mempunyai kesadaran Politik dan Keamanan yang cukup tinggi, sehingga mendukung kondisi keamanan yang sangat konduktif. Kota Binjai sebagai Kota jasa, Perindustrian, Perdagangan dan Pemukiman telah berupaya memacu laju pertumbuhan Pembangunan yang mendukung Pertumbuhan Pembangunan yang mendukung Pertumbuhan Ekonomi Kota Binjai. Sementara itu Pendapat Asli Daerah (PAD) Kota Binjai pada tahun 2008 Rp.13.845.485.199. Sementara Pendapatan Domestik Regional Bruto (PDRB) berdasarkan Harga Berlaku tahun 2008 sebesar 15,04 persen. Hal ini menunjukkan kenaikan jika sebelumnya yaitu sebesar 14,58 persen pada tahun 2007. Laju pertumbuhan ekonomi Kota Binjai atas dasar harga konstan pada tahun 2008 sebesar 5,35 persen, Hal ini menunjukkan penurunan sedikit 
jika dibandingkan dengan tahun 2007 yaitu sebesar 5,68 persen (Sumber: http://www.binjaikota.go.id).

\subsection{Analisa Permasalahan Mitra}

Program studi Teknik Komputer Jaringan di SMK Tunas Pelita dan SMK Abdi Negara dalam proses belajar mengajar mengikuti kurikulum sesuai dengan standard pemerintah, sehingga siswa-siswi memiliki kemampuan dasar untuk design dan instalasi jaringan. Mengingat saat ini pendidikan dalam bidang ilmu komputer yang sangat berkembang pesat baik dalam tingkat sekolah menengah maupun tingkat perguruan tinggi, menjadikan tantangan bagi lulusan SMK karena banyaknya kompetitor dan kuatnya persaingan baik dari tingkat SMK maupun dari tingkat lulusan perguruan tinggi. Secara umum siswa-siswi SMK memiliki pengetahuan umum tentang arsitektur jaringan, topologi, Ip addres, Mikrotik, pengkabelan, setting miktorik, wifi. Dalam hal konfigurasi mereka hanya mampu untuk setting maupun design untuk personal. Selain kemampuan dalam teknologi jaringan komputer, siswa-siswi juga memperoleh pengetahuan dalam bidang wirausaha yang di dapat dari bangku sekolah.

Melihat kemampuan siswa-siswi dalam hal kemampuan dasar untuk membangun jaringan komputer serta pengetahuan dalam bidang wirausaha, sehingga siswa-siswi SMK Taman Siswa dan Swa Karya sangat potensial untuk dikembangkan sehingga mampu berwirausaha dalam hal membangun infrastruktur jaringan komputer dan internet, mampu membangun jaringan internet di warnet dan internet masuk desa. Mengingat sekarang ini perkembangan dunia infomasi dan komunikasi sangat pesat, tidak hanya diperkotaan tetapi juga sampai ke pedesaan. Wirausaha dalam hal penyediaan jasa pembangunan jaringan internet sangat menjanjikan.

\section{Solusi Dan Target Luaran}

\subsection{Solusi Yang Ditawarkan}

Penerapan Ipteks melalui pengabdian masyarakat, kami sebagai dosen Tim dari STMIK Kaputama akan melatih siswa siswi SMK Tunas Pelita dan SMK Abdi Negara untuk membangun jaringan internet untuk warnet, kantor dan jaringan internet desa mencakup: Perakitan Komputer, Install Sistem Operasi pada client, Konfigurasi interface jaringan dan Mikrotik, Konfigurasi IP Addres, Konfigurasi Gateway, Konfigurasi DNS Server, Konfigurasi NAT, 
Konfigurasi DHCP, Subnetting, Membangun Server, MembangunProxy, Membangun Firewall, Management Bandwidth.

\subsection{Target Luaran}

Luaran wajib dari program IbM ini akan disebarluaskan dalam bentuk publikasi pada jurnal nasional/internasional dan media massa, dan target luaran yang diharapkan adalah :

1. Siswa/i SMK Tunas Pelita dan SMK Abdi Negara mampu melakukan perakitan komputer dan install sistem operasi.

2. Siswa/i SMK Tunas Pelita dan SMK Abdi Negara mampu membangun jaringan komputer dan internet untuk warnet, perkantoran dan jaringan pedesaan.

3. Siswa/i SMK Tunas Pelita dan SMK Abdi Negara mampu berwirausaha sebagai penghasilan tambahan khususnya penyedia jasa layanan intalasi jaringan komputer dan internet serta maintenance.

4. Siswa/i SMK Tunas Pelita dan SMK Abdi Negara turut serta membantu pemerintah mengurangi pengangguran dengan adanya wirausaha dan membuka lapangan kerja membangun jaringan internet dan komputer.

5. Membantu kabupaten Langkat, Deli Serdang dan Kota Binjai untuk percepatan akses internet dan informasi hingga ke pelosok.

6. Membantu masyarakat kabupaten Langkat, Deli Serdang dan Kota Binjai untuk mengenalkan produk UKM lewat internet hingga ke selururuh penjuru

7. Meningkatkan wawasan dan pengalaman guru dan Siswa/i SMK Tunas Pelita dan SMK Abdi Negara khususnya tentang perakitan komputer, install sistem operasi, jaringan komputer dan internet

8. Menambah minat masyarakat khususnya lulusan SMP untuk mengambil jurusan Teknologi Komputer Jaringan

9. Terjalinnya hubungan sinergi antara perguruan tinggi dengan sekolah menengah

10. Menjadi mitra pemerintah dalam membuka lapangan kerja Wujud nyata pengabdian masyarakat ini akan diterbitkan di Jurnal Nasional.

\section{Metode Pelaksanaan}

Untuk lebih jelasnya metode pelaksanaan pengabdian IbM yang diusulkan dapat di laksanakan dalam beberapa tahap (Faradisa, 2015), yang digambarkan pada gambar 1. Flowchar Pelaksanaan dibawah ini : 


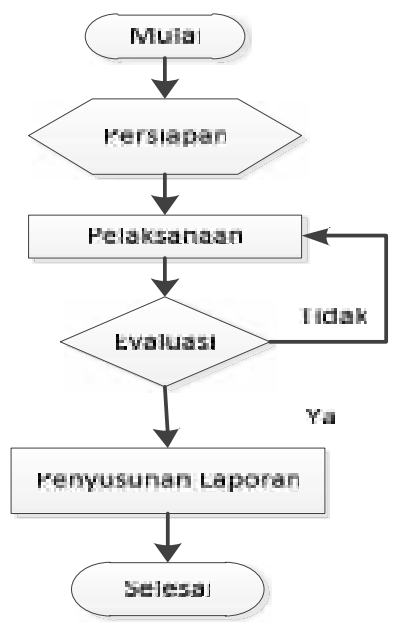

\section{Gambar 1. Flowchart Pelaksanaan}

Tahapan kegiatan pengabdian kepada masyarakat ini melalui beberapa tahapan, meliputi persiapan, pelaksanaan dan evaluasi.

\subsection{Persiapan}

Tahap persiapan dilakukan beberapa kegiatan, yaitu :

Survei tempat pelaksanaan kegiatan, dalam hal ini adalah SMK Tunas Pelita dan dan SMK Abdi Negara.

- Wawancara dilakukan dengan Kepala Sekolah SMK Tunas Pelita yaitu Bapak EMRI Yulizal Ardi, S.Pd, dan Kepala Sekolah SMK Abdi Negara yaitu bapak Suparmin, S.Pd dengan tujuan untuk mengumpulkan data siswa dan terkait dengan keutuhan-kebutuhan pelatihan yang direncanakan

Pembuatan modul, modul pelatihan dibagi menjadi tiga belas bagian sesuai dengan pelaksaan kegiatan

\subsection{Pelaksanaan Kegiatan}

Rencana pelaksanaan kegiatan dibagi menjadi beberapa tahap, yaitu :

1. Pelatihan Perakitan Komputer, Install Sistem Operasi pada client, Konfigurasi interface jaringan dan Mikrotik, Konfigurasi IP Addres

2. Pelatihan Konfigurasi Gateway, Konfigurasi DNS Server, Konfigurasi NAT, Konfigurasi DHCP, Subnetting 
3. Pelatihan Membangun Server, Membangun Proxy, Membangun Firewall, Management Bandwidth

4. Pelatihan Kofigurasi dan instalasi jaringan Warnet

5. Pelatihan Konfigurasi dan instalasi jaringan perkantoran

6. Pelatihan Konfigurasi dan instalasi jaringan internet desa

\subsection{Evaluasi}

Tahapan ini dilakukan untuk mengetahui tingkat keberhasilan kegiatan, sehingga dapat dilakukan penyempurnaan apabila ditemui kekurangan-kekurangan selama kegiatan pelatihan dilaksanakan.

Rancangan Evaluasi

Evaluasi ini bertujuan untuk mengetahui apakah terdapat peningkatan kemampuan siswa setelah dilakukannya pelatihan.

Evaluasi dilakukan dengan dua cara meliputi :

a. Pemberian Tugas :

$>$ Membuat sebuah rancangan pembangunan internet perkantoran, dengan menjelasakan gambaran jaringan dan seting ip dan internet

$>$ Membuat sebuah rancangan pembangunan internet desa, dengan menjelasakan gambaran jaringan dan seting ip dan internet

b. Ujian Praktikum

$>$ Trouble shooting komputer

$>$ Perakitan komputer dan instalasi komputer

$>$ Instalasi jaringan dan internet

c. Kuisioner :

Dimaksudkan untuk mengetahui pendapat dari peserta pelatihan mengenai kegiatan ini, sehingga dapat diketahui apakah tujuan dari kegiatan ini sudah tercapai atau belum.

d. Penyusunan Laporan

Penyusunan Laporan terbagi menjadi dua laporan kemajuan dan laporan hasil.

\section{Hasil Yang Dicapai}

Pengabdian IbM Pelatihan Perakitan Komputer, Install Sistem Operasi Dan Pemasangan Jaringan Lokal Dan Internet Untuk Membangun Jaringan Warnet, Perkantoran Dan nternet Desa Dalam Meningkatkan Kemandirian Siswa SMK Tunas Pelita Dan SMK Abdi Negara Kota Binjai dilaksanakan 
sejak bulan Juni 2016. Adapun kegiatan-kegiatan yang telah dilakukan adalah sebagai berikut :

1. Sosialisasi akan diadakannya kegiatan pengabdian IbM pada Kepala Sekolah dan siswa SMK oleh tim pengabdian

2. Peninjauan lokasi tempat pendirian tiang pipa pemancar Akses Poin pada kedua mitra pengabdian pada SMK Tunas Pelita dan SMK Abdi Negara

3. Peninjauan tempat untuk kegiatan pelatihan dalam hal pengecekan ketersediaan alat- dan perangkat yang dibutuhkan selama kegiatan pelatihan kepada mitra pengabdian

4. Identifikasi alat-alat yang dibutuhkan oleh mitra pengabdian

5. Mempersiapkan kegiatan pelatihan kepada mitra pengabdian tentang materi pelatihan.

6. Melaksanakan kegiatan pelatihan pengabdian : Perakitan Komputer, Install Sistem Operasi pada client, Konfigurasi interface jaringan dan Mikrotik, Konfigurasi IP Addres, Konfigurasi Gateway, Konfigurasi DNS Server, Konfigurasi NAT, Konfigurasi DHCP, Subnetting, Membangun Server, Membangun Proxy, Membangun Firewall, Management Bandwidth.

7. Publikasi kegiatan pada Koran Metro Bijai-Langkat secara cetak dan online

\section{Rencana Tahapan Berikutnya}

Adapun rencana tahapan berikutnya yang akan dilakukan adalah :

1. Memantau perkembangan siswa-siswa SMK Tunas Pelita dan SMK Abdi Negara yang telah mendapatkan pelatihan.

2. Melalui grup IbM yang telah dibuat pada group facebook diharapkan menjadi ajang komunikasi antara siswa dan tim pelaksana pengabdian, sehingga pembimbingan dan pembimbingan dapat terus dilaksanakan.

3. Melakukan pendampingan setelah dilakukan pelatihan agar sesuai dengan harapan siswa-siswa dapat mendirikan usaha atau bisnis penjualan koneksi internet pada desa.

4. Melakukan publikasi proseding dan jurnal nasional terkait dengan kegiatan Pengabdian IbM Pelatihan Perakitan Komputer, Install Sistem Operasi Dan emasangan Jaringan Lokal Dan Internet Untuk Membangun Jaringan Warnet, Perkantoran Dan Internet Desa Dalam Meningkatkan Kemandirian Siswa Smk Tunas Pelita Dan Smk Abdi Negara Kota Binjai. 
5. Melakukan testing penyerapan pengetahuan yang didapat oleh siswasiswa SMK Tunas Pelita dan SMK Abdi Negara yang telah mendapatkan pelatihan, dan selanjutnya menerbitkan sertifikat pelatihan.

\section{Kesimpulan Dan Saran}

\subsection{Kesimpulan}

Dari kegiatan pengabdian pada masyarakat ini dapat disimpulkan bahwa:

1. Pengetahuan dan pemahaman siswa-siswi siswa - siswi SMK Tunas Pelita dan SMK Abdi Negara pada setiap sesi pelatihan menjadi meningkat.

2. Keinginan siswa-siswi SMK Tunas Pelita dan SMK Abdi Negara untuk berwirausaha meningkat, khususnya untuk membangun warnet milik sendiri dan menjual koneksi internet pada desa dengan memanfaatkan koneksi akses poin yang telah dipelajari pada saat pelatihan.

\subsection{Saran}

Mengingat besarnya manfaat kegiatan pengabdian pada masyarakat ini, maka selanjutnya perlu:

1. Mengadakan pelatihan serupa pada siswa-siswi SMK yang berbeda serta wilayah jangkauan SMK yang lebih luas.

2. Adanya kesinambungan dan monitoring program pasca kegiatan pengabdian ini sehingga siswa-siswi SMK Tunas Pelita dan SMK Abdi Negara dapat mempraktekan keahlian yang diperoleh selama pelatihan di wilayah desa masing-masing.

\section{Ucapan Terima Kasih}

Kami menyampaikan terima kasih yang sebesar-besarnya kepada Direktorat Riset dan Pengabdian Kepada Masyakat (DRPM) Ditjen Penguatan Riset dan Pengembangan Kementerian Riset, Teknologi, dan Pendidikan Tinggi atas dukungan dana berupa hibah pengabdian Iptek bagi Masyarakat (IbM) tahun anggaran 2016. Kami juga mengucapkan terimakasih kepada mitra SMK Tunas Pelita Dan SMK Abdi Negara Kota Binjai atas pelaksanaan kegiatan pengabdian ini. 


\section{Daftar Pustaka}

Faradisa,S.I. dan Santi,F.W. dan Wahyuni,Y. 2015, "IbM Pelatihan Dan Pendampingan Pembuatan Media Pembelajaran Interaktif Untuk Guru Sekolah Dasar Kelurahan Tasikmadu Dan Kelurahan Tunjungsekar Kotamadya Malang" , PROSIDING SEMINAR NASIONAL "RESEARCH MONTH" 2015 "Sinergi Hasil Penelitian dan Pengabdian kepada Masyarakat untuk Menumbuhkan Kapasitas Inovasi di Bidang Teknologi, Pertanian, Sosial dan Ekonomi". ISBN:978-602-0856-43-8.

Fitriasih,S.H. dan Utami,Y.R.W. dan Kustanto, 2009 "Pelatihan Trouble Shooting Komputer untuk Karang Taruna Desa Banaran Kelurahan Banaran Kecamatan Grogol Kabupaten Sukoharjo", Jurnal Ilmiah SINUS, Vol.7, No.2, ISSN : 1693 - 1173.

Wulandari,B. dan Suparman dan Santoso,D dan Muslikhin dan Utami.A.D.W, 2015, "Pengembangan Trainer Equalizer Grafis Dan Parametris Sebagai Media Pembelajaran Mata Kuliah Praktik Sistem Audio", Jurnal Pendidikan Teknologi Kejuruan, e-ISSN 24772410,p-ISSN 0854-4735.

http://langkatkab.bps.go.id, diakses 25 April 2016

http://migas.bisbak.com/, diakses 25 April 2016 